Preprints of the

Max Planck Institute for

Research on Collective Goods

Bonn 2008/13

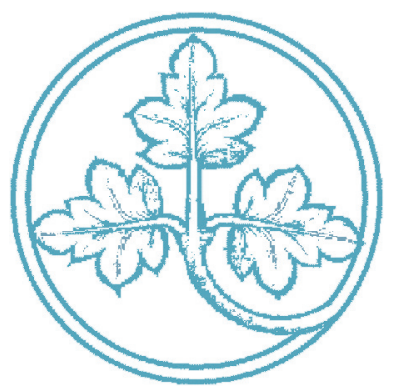

Cartels, managerial incentives, and productive efficiency in German coal mining, 1881-1913

Carsten Burhop / Thorsten Lübbers

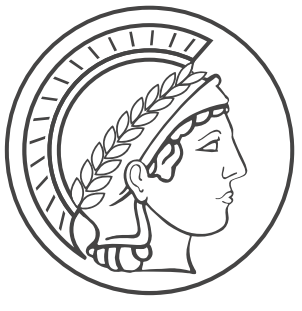




\section{Cartels, managerial incentives, and productive efficiency in German coal mining, 1881-1913}

Carsten Burhop / Thorsten Lübbers

April 2008 


\title{
Cartels, managerial incentives, and productive efficiency in German coal mining, 1881-1913*
}

\author{
by \\ Carsten Burhop ${ }^{\dagger} /$ Thorsten Lübbers
}

\begin{abstract}
In this paper, we evaluate the impact of cartelisation and managerial incentives on the productive efficiency of German coal mining corporations. We focus on coal mining in the Ruhr district, Germany's main mining area. We use stochastic frontier analysis and an unbalanced dynamic panel data set for up to 28 firms for the years 1881-1913 to measure productive efficiency. We show that coal was mined with decreasing returns to scale. Moreover, it turns out that cartelisation did not affect productive efficiency. Controlling for corporate governance variables shows that stronger managerial incentives were significantly correlated with productive efficiency, whereas the debt-equity ratio did not influence it.
\end{abstract}

JEL-Classification: N 53, L 41, L 71

Keywords: Economic history; Germany pre-1913; Cartel; Productive efficiency; Corporate Governance

\footnotetext{
* We would like to thank Martin Hellwig, Felix Höffler, Ulrich Pfister, two anonymous referees, seminar participants at the University of Münster, participants of the European Historical Economics Society meeting 2007 and our colleagues at the Max Planck Institute for Research on Collective Goods for helpful comments and suggestions. Darrell Arnold and Brian Cooper substantially improved the writing. All remaining errors are the sole responsibility of the authors. In addition, we would like to thank Marina Boland, Kathrin Datema, Eva große Kohorst, Annika Petersen, Juliane Schrader, and Hendrik Voss for substantial support in collecting the data for this article. An earlier version of this paper was written while the authors were researchers at the Institute of Economic and Social History, University of Münster. Financial support of the Fritz-Thyssen-Stiftung is gratefully acknowledged.

$\dagger \quad$ email: burhop@coll.mpg.de
} 


\section{Introduction}

Economic theory has developed a rich set of predictions regarding the behaviour and success of cartels (Levenstein and Suslow, 2006, review the literature). One main conclusion derived from theoretical models is that the incentives of individual firms to cheat undermine the stability of cartels. Therefore, cartels should be short-lived. Indeed, most cartels break up very quickly, and the average duration of a cartel is only about five years. Nevertheless, some cartels survive for very long periods. The fact that cartels survive for long periods of time can be taken as evidence for economic success, at least from the point of view of the participating firms. Yet, the consequences of long-lived cartels and their impact on economic variables like output, prices, profits, and productivity have only been partly identified by empirical research.

In particular, empirical studies investigating the effects of cartels focus on price data. They partially compare pre-cartel and cartel prices, prices between calm periods and cartel price wars, or national and international prices. Price differentials are then taken as evidence for the monopoly power of the cartel. Overall, there is substantial evidence that cartels induce rising prices. On the other hand, empirical evidence regarding the impact of cartels on other important economic variables, e.g., on firm profits, market structure, or output, is rare. The effects of cartels on the productive efficiency of the cartelised firms have been more or less neglected (Levenstein and Suslow, 2006: 84). However, social losses can result not only from rising prices and falling output under monopoly conditions, but also from the declining cost efficiency of production.

Most of the very few empirical studies investigating the relationship between cartels and productivity focus on productivity growth, i.e., the question whether cartels assist or constrict rises in total factor productivity, whereas the question of technical efficiency is neglected. On the one hand, Webb (1980) argues that the German steel cartel of the late $19^{\text {th }}$ and early $20^{\text {th }}$ century contributed to increased investment and productivity. On the other hand, Fine (1990), as well as Broadberry and Crafts (1992), argue that at least part of Britain's productivity decline during the $20^{\text {th }}$ century can be attributed to its permissive attitude towards collusion. Turning to static efficiency, Audretsch (1989) has argued that in post-1945 West Germany cartels were associated with reduced output rather than lower costs. This implies that cartels led to reduced cost efficiency. ${ }^{1}$

One reason for the relatively small number of empirical studies regarding the productivity effects of cartels might be the difficulty to obtain sufficient data. Most cartels operate secretly since many countries make cartels illegal. In the US, for example, cartels have been interdicted since the 1890 Sherman Act. Contrary to the US or to modern Germany, cartel agreements were legally binding and enforceable in late $19^{\text {th }}$ and early $20^{\text {th }}$ century Germany (see Cheffins, 2003), making historical data from Germany an ideal empirical base for testing cartel theories.

1 A few authors have investigated the relationship between product-market competition and productivity. Winston (1998) reports evidence of productivity gains for a set of industries after deregulation. Zitzewitz (2003) finds a positive relationship between product-market competition and productivity in the US and UK tobacco industry during the late 19 th and early 20 th century. 
In this paper, we focus on the impact of one of the longest-lasting cartels in the world, the Rhenish-Westphalian Coal Syndicate (Rheinisch-Westfälisches Kohlensyndikat, RWKS), specifically on the productive efficiency of German coal-mining corporations between 1881 and 1913. The RWKS was founded in 1893 and was dissolved by the Allied Forces in 1945 (Levenstein and Suslow, 2006: 53). It would therefore qualify as a successful cartel if cartel duration is a measure of success. The cartel was formed during the period of Germany's rise to industrial power; this rise has traditionally been ascribed to its dynamic steel, chemical, and electrical engineering corporations (Gerschenkron, 1962; Landes, 1969). Germany is often viewed as having overtaken Britain by leapfrogging ahead of it, employing an economic model closer to the successful model of American managerial capitalism than to the supposedly failed model of British personal capitalism (Chandler, 1990). One important component of Germany's managerial capitalism was the coordination of economic activities via various institutional arrangements. Interlocking directorates, close relationships between banks and industry, and, last but not least, cartels were coordination mechanisms well established in Germany at the turn of the $20^{\text {th }}$ century. Whereas the relevance of interlocking directorates and of close bank-industry relationships has been intensively investigated (Fohlin, 2007, reviews the literature), the economic impact of cartels has not been fully identified.

During the early $20^{\text {th }}$ century, nearly 400 cartels controlled about one-quarter of the total industrial and mining output in Germany. Cartels are supposed to have lessened the intensity of competition and to have led to greater steadiness of production and prices (Kocka, 1978: 563). Moreover, at least some of the cartels might have influenced the allocation of production factors. For example, more stable prices and output reduced the risk of cartelized steel firms, which in turn induced higher rates of fixed-capital investment. Comparatively high capital-labour ratios then resulted in high labour productivity, but without leading to inefficiency due to overinvestment (Webb, 1980). In addition, it seems that at least some cartels did not achieve excess profits. More specifically, Peters (1989) argues that the RWKS primarily aimed to stabilise prices and output and not to achieve excess profits. This hypothesis is supported by the findings of Bittner (2002, 2005); he shows that the formation of the RWKS in 1893 did not led to excess returns for the participating firms in the stock market. Yet, perhaps the managers of cartelized coal mining corporations did not use market power to attain pecuniary monopoly profits. This could explain the poor stock market reaction to cartel formation. Perhaps they followed a strategy hypothesised by Hicks (1935), i.e., that the best monopoly profit is a quiet life for the manager. Germany's managerial capitalism would then have been less successful than supposed by Chandler (1990). ${ }^{2}$

Since Hicks proposed his famous hypothesis, the managerial economy has been investigated in more detail theoretically. In particular, in a world with symmetric information between managers and owners of a company, managers will minimise costs; as a result, the company is technically

2 Moreover, Chandler (1990) figured out that cartelisation instead of mergers impeded the emergence of efficient firm sizes in Germany. Consequently, productivity was substantially lower in Germany than in the U.S. In addition, Tullock (1967) argues that a monopolist will use at least some of his rent to defend his position, e.g., by influencing the government or by prohibiting market entry. These activities consume resources, and therefore productive efficiency declines. 
efficient. Yet, if asymmetric information between managers and shareholders exists, managers need to be motivated, e.g., by bonus payments, to achieve the first-best solution. The optimal design of such managerial incentives is influenced by product market competition - along with other factors. First of all, if managers can describe monopoly profits as profits resulting from managerial effort, the signal received by the principal becomes more diffuse and it becomes more difficult to design incentives optimally (Hart, 1983). In addition, low product market competition reduces the bankruptcy risk of firms - and thereby the lay-off risk for managers - which might reduce managerial effort and company efficiency. However, if managers get a share of the profit, they still put effort into the firm. Moreover, since the marginal return of managerial effort is higher in a world with low product market competition, managers will increase their effort and thereby the efficiency of the firm (Schmidt, 1997). In addition, the negative correlation between market power and bankruptcy risk can be counteracted by the principals via the choice of the financial structure of the firm. Bankruptcy risk increases with the debt-equity ratio; therefore, the effects of market power on the managerial effort can be counteracted by increasing debt relative to equity (Aghion et al., 1999). Thus, the effects of cartel formation on productive efficiency can only be fully accounted for if corporate governance variables are taken into consideration.

If managers actually enjoyed a quiet life, instead of the hard life of profit-maximising agents, cartelised coal mines would exhibit lower productive efficiency. We test this hypothesis by estimating a stochastic frontier model using input and output data of up to 28 coal mining corporations for the period 1881-1913. It turns out that the productive efficiency of coal-mining corporations was not significantly affected by cartel membership. Moreover, a high debt-equity ratio also left productive efficiency unaffected. On the other hand, productive efficiency was significantly higher in firms that paid large bonuses to their board members. This indicates that compensation schemes were more important for conserving productive efficiency than competitive pressure from product markets or the higher bankruptcy risk of highly leveraged firms.

The remaining parts of the paper are organised as follows. In Section II, we describe the organisation of coal mining in Germany between 1880 and the First World War. Data sources and descriptive statistics are presented in Section III. In Section IV, we outline the econometric method employed. In Section V, we measure firm-level productive efficiency using stochastic frontier analysis. Section VI concludes the paper.

\section{The Rhenish-Westphalian Coal Syndicate}

The three decades from the 1880s to World War I constitute the later phase of Germany's industrialisation. Real net national product increased by 159 percent between 1880 and 1913 and industrial output by 202 percent (Burhop and Wolff, 2005). One important factor behind this rapid growth was coal, the main energy source of the day. In particular, metal production, metal processing, chemicals, mining, and transportation relied on coal as an input factor. Furthermore, coal was an important consumption good, used as heating material in the growing urban centres in 
Germany (Holtfrerich, 1973: 129-154). ${ }^{3}$ Coal was basically supplied by four sources. The most important German mining districts were the Ruhr district in the west, the Saar area in the southwest, and Silesia in the east of the empire. Furthermore, coal was imported from Britain via Hamburg, Germany's primary seaport. The most important source was the Ruhr district, whose mines supplied about 48 percent of German coal output in 1880 and about 58 percent in 1913 (Jahrbuch, 1914: 748).

The quantitative importance of Ruhr coal mining for the German economy is one reason for focusing on it. Moreover, the industrial organisation of coal mining in the Ruhr district differed significantly from the organisation in other parts of Germany. In the Ruhr district, mining was almost exclusively performed by publicly traded corporations, organised either as corporations (Aktiengesellschaft) or as Gewerkschaft. ${ }^{4}$ In the Saar area, the Prussian state was by far the largest player. In Upper Silesia, the government also had significant shares in output, but in this area, most of the coal fields were privately owned and extracted by East-Elbian aristocrats (Pierenkemper 1992; Walker, 1904: 34-35).

Already at the end of the 1870 s, collusion had become a prominent phenomenon in the Ruhr district. By coordinating individual behaviour, the mining firms sought to eliminate what they thought to be "unhealthy" (ungesunde) competition, and thereby to secure what was called "sufficient" (auskömmliche) prices and profits. ${ }^{5}$ Early efforts were aimed at controlling either output or prices. Moreover, even if more sophisticated coordination techniques were used, they were restricted to local areas and lacked mechanisms to punish defectors. As a result, up to the beginning of the 1890s, all collusive arrangements were ineffective in pursuing their goals, and they therefore eventually failed. ${ }^{6}$

In 1893, 98 firms, representing 87 percent of the coal output from the Ruhr district (Passow, 1911: 68), joined to form the RWKS, commonly referred to as the most powerful collusive arrangement in Imperial Germany (Parnell, 1994: 29). Its original treaty was revised twice, first in 1896 and for a second time in 1903. With the latter revision, the vertically integrated iron and steel producers, the foundry mines (Hüttenzechen), of the district, which had abstained from membership up to then, joined the cartel. As a result, coal extraction in the Ruhr district was almost completely cartelised (the market share at the end of 1903 was 98.7 percent).

3 Between 1904 and 1912, about 40 percent of coal was consumed by the iron and steel industry, 15 percent by private households, and 10 percent by railways. Moreover, 10 percent were exported.

4 A Gewerkschaft was a legal type of enterprise exclusively designed for mining. Its capital was divided in (up to 1,000 ) mining shares (called Kux), which did not represent a certain amount of capital, but a percentage share of the firm. In contrast to corporations, the owner of a Kux did not only profit from distributions (called Ausbeute), but was also obliged to remargin capital (called Zubuße) to finance investments or accrued losses. Moreover, since they were registered, the trading of a Kux was subject to harsher restrictions than the buying or selling of stocks (Friedrich, 1979).

5 The cited terms can be found in the annual reports of the Verein für die bergbaulichen Interessen im Oberbergamtsbezirk Dortmund, cited in Passow (1911).

6 A detailed description of the predecessors of the Rhine-Westphalian Coal Syndicate can be found in Verein (1904b). 
The RWKS was a price- and quota-setting cartel. ${ }^{7}$ In addition, it managed the sales of its members' production. Every participating firm had to commit itself to sell its entire output to the cartel, which in return was obliged to purchase it. Mines that failed to meet their delivery requirements without a valid excuse were punished with a fine. The prices the RWKS charged its customers varied according to the place where the respective coal was sold. In what was known as the 'undisputed area' (unbestrittenes Gebiet), the cartel enjoyed advantages in transportation costs that prohibited outsiders from competing. Here, it fixed its prices annually. Variations were only allowed to account for differences in quality. In contrast, prices in the disputed area (bestrittenes Gebiet) were determined competitively. If they fell short of those in the noncompetitive region, the cartel would compensate for the difference. The compensations (as well as the cartel bureaucracy) were financed by a variable percentage deduction from the monthly revenues that the cartel transferred to its members (Umlage).

Production was regulated by assigning each member a participation figure (Beteiligungsziffer), which was allotted on the basis of members' production levels in either 1891 or 1892 . The figures were expressed in tons of coal production, but served as quotas that defined a member's share in total output, since the sum of the individual participation figures represented the maximum production capacity of the cartel. In practice, this maximum was hardly ever realized, because the cartel authorities could reduce total output by applying a common percentage reduction to each member's figure if they judged the production capacity to surpass demand. ${ }^{8}$ Cartel members that exceeded their production allowance were punished with severe fines. Mines, which had to produce below their allowed output due to quality problems or delivery commitments, received subsidies.

Given the duration, the impressive market share, and the seemingly tight organization, it seems reasonable to assume that the RWKS was effective in controlling prices and output. On average, price variations for coal declined after the cartel formation. ${ }^{9}$ Moreover, the cartel nearly achieved its output target in most years (Peters, 1981: 146). Yet, there were obstacles that might have prevented the cartel from successfully pursuing its cause. One reason may be that, due to the large number of firms, negotiation and monitoring costs were presumably high. Moreover, cost structures were heterogeneous since the geological conditions varied substantially between mines in the north and the south of the Ruhr district. Finally, the industry was dynamically growing and the output of cartel outsiders was continuously increasing. ${ }^{10}$

Furthermore, Peters $(1981,1989)$ has persuasively argued that the long duration of the RWKS was largely due to the flexibility of its contracts. In particular, the regulation of output allowed the cartel members to behave individualistically. Their participation figures were not perma-

$7 \quad$ The texts of the three contracts are published in Verein (1904b).

8 Between 1893 and 1914, there were only two years $(1900,1907)$ when no reduction was enforced (Peters, 1981: 144-145).

9 Coal prices are available at the NBER historical statistics homepage.

10 Up to 1903, the most important outsiders in the undisputed territory were the foundry mines. After 1903, the Prussian state became increasingly important. 
nently fixed. There were several different ways to increase them. ${ }^{11}$ During the period in which the first two contracts were valid (1893-1903), a member could automatically increase his participation figure if he sank a new production shaft. ${ }^{12}$ When this was registered, the cartel authorities had almost no means to reject the request for a higher quota. Moreover, all firms could request a higher participation figure for already existing shafts. In contrast to the procedure applied for new shafts, the responsible body of the RWKS could refuse an increase if it judged that the coal market was incapable of dealing with extra production. The takeover of another cartel member was a third way to achieve a higher participation ratio, without changing the sum of production allowances. Subsequently, the re-allocation of production allowances among firms via takeovers could be one way to achieve a higher technical efficiency on average, since firms could shut down the least efficient shafts. ${ }^{13}$

Between 1893 and 1913, the sum of the individual production allowances rose from 35.4 to 84.1 million tons (Jahrbuch, 1914: LXX). Many new shafts were drilled to get an additional quota: new shafts were sunk and then closed again as soon as the higher quota was assigned; ventilation shafts were converted to extraction shafts; single shafts were equipped with additional extraction facilities and thereby turned into double shafts, which were counted as two shafts (Peters 1981, 1989). In effect, the constant changes in the relative and absolute importance among its members must have seriously hampered the ability of the cartel bodies to control output effectively. ${ }^{14}$

Finally, simply looking at the combined market shares of its members overstates the market power of the RWKS. First of all, the cartel sold less than 50 percent of its total output in the undisputed territory; the remaining coal had to be marketed at competitive prices (Wiedenfeld, 1912: 79, 101). Furthermore, occasionally exports had to be subsidised with revenues from sales in the undisputed territory, as they were conducted below domestic market prices. Moreover, collusion on the demand side or large customers might have restricted the market power of the RWKS. For example, 40 percent of the coal was supplied to the iron and steel industry, which was also cartelized to some extent. In addition, ten percent of the coal was supplied to railways, which were mainly state-owned. Yet, the impact of downstream market power on the price formation at the coal market has never been investigated. ${ }^{15}$ In addition, after the second revision of the contract the grip of the cartel on the output of its members began to loosen. Right from the

11 For an individual firm, a higher participation figure was extremely desirable: If other members did not increase their figures simultaneously, an enlargement would result in a higher individual share in total output. By this, the respective cartel member could augment its coal production and circumvent reductions enforced by the cartel authorities. In addition, the weight in the price- and production-setting committees of the RWKS depended on the share in total output. If fellow colluders also increased their production allowances, an enlargement of one's own participation figure was necessary to at least keep one's relative position in the organisation.

12 The participation figure was then increased by 120,000 tons.

13 All three contracts stipulated that the members of the RWKS were allowed to distribute freely their individual quota among their production facilities. Thus, since acquiring a cartel member also meant taking over its participation figure, an acquiring firm could redistribute output to its most efficient facilities without restriction.

14 Between 1895 and 1914, the actual output of the cartel exceeded the projected output in eleven of twenty years (Peters, 1981: 147).

15 See, e.g., Webb (1980) and Feldenkirchen (1982: 110-124) for a description of the industrial organisation of the iron and steel industry. 
foundation of the RWKS, the coal used to run operations (Selbstverbrauch) was excluded from the members' delivery commitments. Up to 1903, these provisions applied to the share of output that was needed to run steam engines and used to produce coke or briquettes. Although it did not have to be delivered to the cartel, it was nonetheless subject to control through the quota regime. After 1903, the coal for running iron and steel works was also declared to be a part of the Selbstverbrauch. Moreover, in order to persuade the vertically integrated firms to join the organisation, coal for self-use was no longer controlled by cartel quotas.

\section{Data sources and descriptive statistics}

Our sample covers up to 28 mining corporations from the Ruhr district. Data about Gewerkschaften could not be obtained, as they were not obliged to publish the same details about their business operations as corporations were. The firms in the sample represent between 28 percent (in 1881) and 58 percent (in 1907) of the coal output from this region and 14 percent (in 1881) to 33 percent (in 1907) of the German coal output.

Table 1: Descriptive Statistics

\begin{tabular}{ccccc}
\hline Firm specific mean & $\begin{array}{c}\text { All observations } \\
1881-1913\end{array}$ & $\begin{array}{c}\text { All firms, 1893- } \\
1913\end{array}$ & $\begin{array}{c}\text { Cartelized } \\
\text { firms, 1893- } \\
1913\end{array}$ & $\begin{array}{c}\text { Non-cartelized } \\
\text { firms, 1893- } \\
1913\end{array}$ \\
\hline Coal output in tons & $1,173,752$ & $1,501,965$ & $1,607,747$ & 497,033 \\
Number of workers & 4,389 & 5,688 & 6,055 & 2,204 \\
Capital stock in Marks & $24,268,828$ & $31,089,364$ & $32,963,540$ & $13,284,699$ \\
Return on capital & $8.5 \%$ & $8.8 \%$ & $8.5 \%$ & $15.6 \%$ \\
Marks & 73,574 & 96,671 & 101,360 & 52,119 \\
Incentive pay for board members in & & & $3.6 \%$ & $2.5 \%$ \\
Profit share of board & $3.6 \%$ & $3.5 \%$ & $26.5 \%$ & $34.7 \%$ \\
\hline Debt ratio & $24.8 \%$ & $27.3 \%$ & 28 & 4 \\
\hline Number of cross sections & 28 & 28 & 380 & 40 \\
\hline
\end{tabular}

Source: see Appendix 1 and 2.

Output and input data were collected from a variety of sources. See Appendices 1 and 2 for a detailed list of firms included in our sample and the exact sources. To estimate a production frontier, output and input measures are required. Our output measure is tons of coal produced during a year; input measures are the number of workers ${ }^{16}$ and the value of the fixed assets of a firm, calculated from balance-sheet data. Accounting figures do not necessarily display the economic value of assets; we therefore apply the perpetual inventory method to compute the capital stock

16 We implicitly assume an identical relation between total employment and the underground workers for all firms. Furthermore, one should note that the number of annual working hours per underground worker was nearly constant over the whole period under consideration. 
of firms. We use a method proposed by Lindenberg and Ross (1981). Following their approach, the book value of a firm is adjusted for investment, depreciation, price changes, and the technological progress of the current and of preceding periods (for a detailed description, see Appen$\operatorname{dix} 3)$.

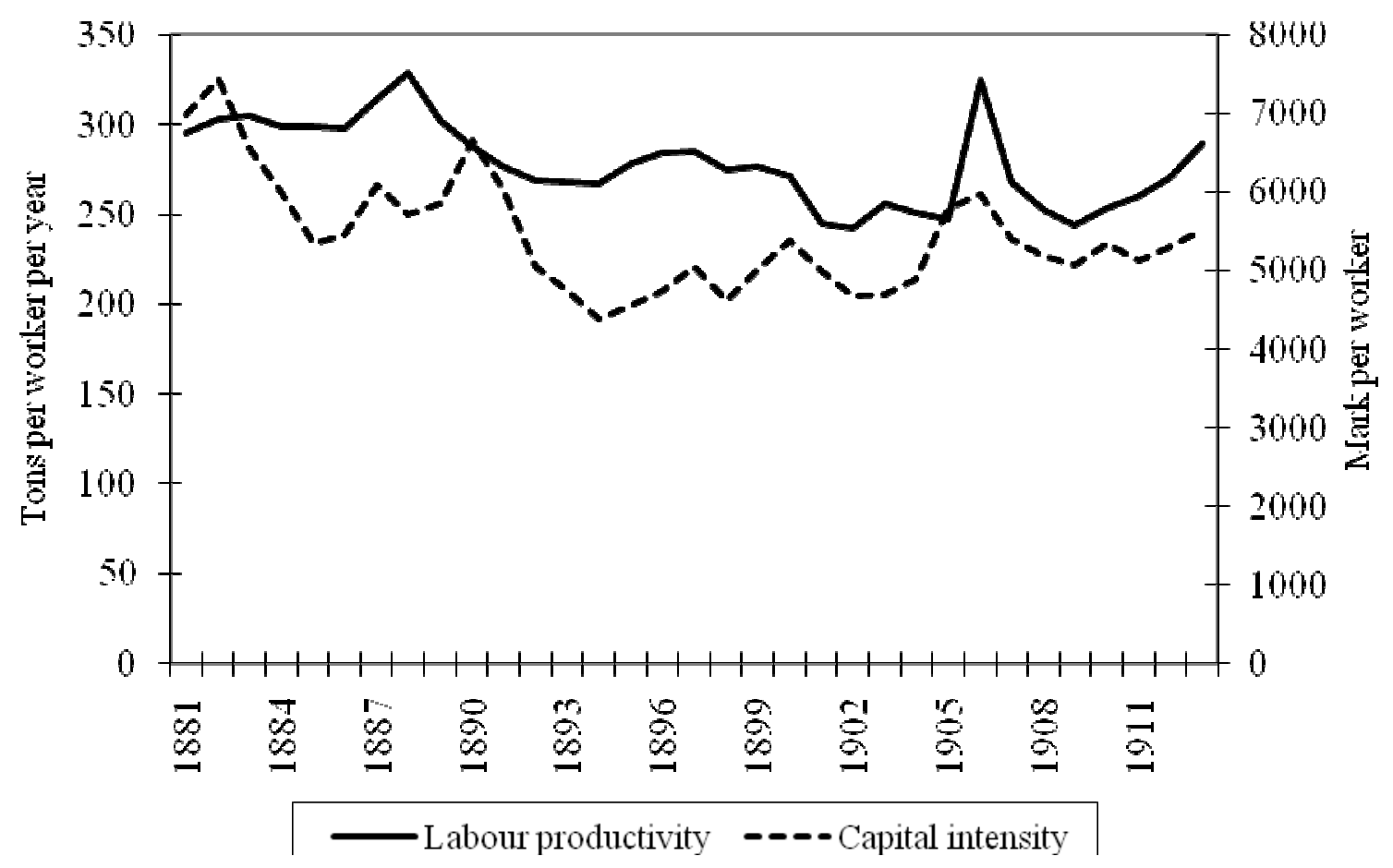

Figure 1: Labour productivity and capital intensity of our sample of Ruhr district coal mining corporations, 1881-1913. Source: see Appendix 1.

The aggregated input and output figures of the sample clearly show the continuing growth process that characterised the German mining industry between 1881 and 1913. The coal extraction of the 28 firms increased from 5.7 million tons to 43.9 million tons (682 percent); capital input increased from 135.5 million Marks to 865.3 million Marks (538 percent), and labour input from 19,315 workers to 150,890 workers (681 percent). As can be seen in Figure 1, labour productivity, measured in tons per worker, was thus nearly constant, whereas the capital intensity slightly declined between 1881 and $1913 .^{17}$

The average coal output of a firm in our sample was nearly 1.2 million tons annually from 1881 to 1913 . This output was produced using a capital stock valued at about 24.3 million Marks and by employing nearly 4,400 underground workers. During the cartel period (1893-1913), the out-

17 This finding contradicts Holtfrerich's (1973) hypothesis of a rising capital intensity. He based the argument on the number of installed horse-powers per worker. As a matter of fact, installed horse-powers per worker increased by about 60 percent from the 1880 s until the early 20 th century (Jahrbuch, various issues). On the other hand, the number of shafts per worker decreased by at least 34 percent over the same period (Jahrbuch, various issues; Verein, 1904a). The accounting data employed in this paper account for these diverging trends of different capital input types. 
put, labour input, as well as capital input of cartelized firms were about 2.5 times larger than of non-cartelized firms. Labour productivity was higher in cartelized firms, whereas capital input per worker was higher in non-cartelized firms. ${ }^{18}$ Non-cartelized firms were much more profitable than cartelized firms; the profit share paid by them to the managers was smaller; and the debt ratio was higher.

22 of the firms were only engaged in coal mining; the remaining six were vertically integrated foundry mines. All of the included firms used a similar technology in exploiting their fields. Due to the characteristic of the coal deposits in the Ruhr area, it was almost exclusively mined with vertically sunk shafts. ${ }^{19}$ Moreover, the technology used to mine the coal seams was, with slight variations, identical: hand labour dominated; mechanical extraction machines were almost completely absent up to the turn of the century; afterwards they were only slowly accepted (Burghardt, 1995; Hoffmann, 1965: 59-60). In contrast to the similarities in the production technology, there were presumably differences between firms from different parts of the district that could have influenced productivity significantly. Mines situated in the south were faced with thinner and less even seams than those in the north. The output of the former displayed a lower ratio of coal to stone. These disadvantages were partly offset by the fact that extraction shafts in the northern part of the district had to be deeper in order to reach deposits that were worth exploiting (Bergmann, 1937; Brown, 1993: 203-229).

The production technology seemed to be similar not only for different firms, but also over time. Labour productivity was nearly constant, and capital intensity was only slightly declining. Moreover, a rather simple estimate of the total factor productivity shows that it was nearly constant between 1881 and 1913. Under the simplifying assumptions of constant returns to scale and a labour share of 0.8 , the total factor productivity - normalized to $1881=100$ - was 105.4 between 1881 and 1892 and 99.6 between 1893 and $1913 .^{20}$

Besides inputs like capital and labour, theory suggests that market structure, managerial incentives, and capital structure could influence efficiency. We use data about performance-related remuneration paid to the executive board and to the supervisory board to measure managerial incentives. The capital structure of each firm is factored into the estimation via the quotient of debt over total assets, the debt ratio. Incentive payments to board members were - in Marks as well as in the share in profits - significantly higher in cartelised than in non-cartelised firms. This is a first indication that principals substituted weaker incentives from product market competition with stronger monetary incentives. On the other hand, the disciplining force of high debt levels was used much more intensively in non-cartelized firms.

18 This contradicts Webb (1980). He hypothesised that cartel membership fostered investment in physical capital.

19 In 1885, the average depth of the shafts in the Ruhr district was 342 metres. In 1908, it was 460 metres. At the eve of the First World War, the maximum depth of up to 1,000 metres was reached (Bosenick, 1906: 30; Goldschmidt, 1912: 11; Jahrbuch, 1914).

The difference between the two sub-periods is statistically insignificant. 
Another important external force influencing managerial effort is competitive pressure from product markets. Product market competition can be measured in a number of ways, for example by the market share of the largest three corporations or a Herfindahl index. However, our econometric method uses company-level data. Therefore, aggregated data about market power are inadequate. We measure the influence of the cartel's market power on the productive efficiency of a firm by a dummy variable, taking the value of one if the firm was a member of the RWKS during a given year. Moreover, we address the effect of the cartel's existence on the productive efficiency of all firms by a dummy variable taking the value of one for all post-1892 observations.

A direct approach to measure market power is the calculation of the Lerner-Index, i.e., the ratio of prices to marginal costs. In the case of perfectly competitive markets, prices equal marginal costs and the price-costs margin therefore takes the value of one. Therefore, price-cost margins higher than one indicate market power. However, calculation of marginal costs is quite difficult. Therefore, we computed the ratio of prices to average costs for a sub-sample of about one-third of our sample. In general, average costs do not equal marginal costs if fixed costs and decreasing returns to scale characterise the production process. Thus, the level of our quasi-Lerner index is uninformative. Nevertheless, a shift in the level of the index after the cartel formation in 1893 serves as an indicator of rising market power under the additional assumptions of constant production functions. Yet, the ratio of prices to average costs was roughly constant between 1881 and 1913. These results casts doubt on the effectiveness of the cartel agreement.

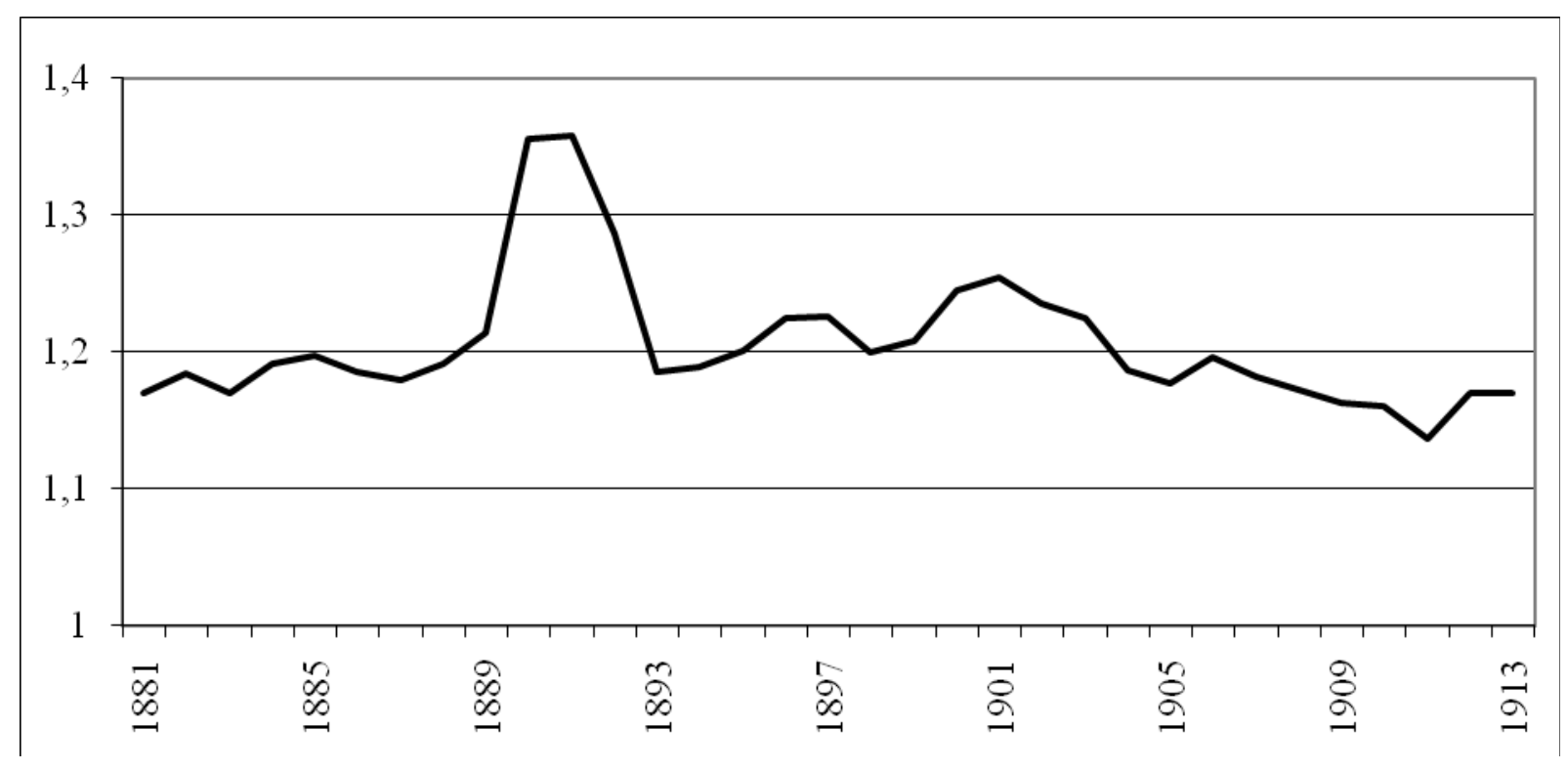

Figure 2: Price-average cost-margin for a sub-sample of corporations, 1881-1913.

Source: see Appendix 1. 


\section{Econometric method}

A standard tool for the estimation of productive inefficiency is stochastic frontier analysis (Greene, 2003: 501; Sickles, 2005). Basically, a production function $y=f(x)$ describes the relationship between a set of input factors $\mathrm{x}$ and output $\mathrm{y}$. For any given $\mathrm{x}, \mathrm{y}$ must be equal to or less than $\mathrm{f}(\mathrm{x})$, i.e., production always takes place on or below the maximum level of the production function. For an empirical regression model of $\mathrm{y}=\mathrm{f}(\mathrm{x})+\varepsilon$, this theoretical consideration implies that the error term $\varepsilon$ must be negative. The canonical solution to this problem was proposed by Aigner et al. (1977). In this framework, any deviation from the production function could arise from two sources: productive inefficiency and idiosyncratic effects that could be either positive or negative. In addition, we add firm-specific fixed-effects $f_{i}$ and $\varphi_{i}$ to the model to capture fixed characteristics of the coal mines, i.e., geological differences between them. ${ }^{21}$

More formally, we estimate production functions described by equations (1a) and (1b). Equation (1a) describes the very general translog production function, whereas (1b) is the standard CobbDouglas production function:

$$
\begin{aligned}
& \text { (1a) } \mathrm{Y}_{\mathrm{i}, \mathrm{t}}=\mathrm{f}_{\mathrm{i}}+\mathrm{a}_{1} \mathrm{~L}_{\mathrm{i}, \mathrm{t}}+\mathrm{a}_{2} \mathrm{~K}_{\mathrm{i}, \mathrm{t}}+\mathrm{a}_{3} \mathrm{~L}_{\mathrm{i}, \mathrm{t}}^{2}+\mathrm{a}_{4} \mathrm{~K}_{\mathrm{i}, \mathrm{t}}^{2}+\mathrm{a}_{5} \mathrm{~L}_{\mathrm{i}, \mathrm{t}} \mathrm{K}_{\mathrm{i}, \mathrm{t}}+\mathrm{v}_{\mathrm{i}, \mathrm{t}}-\mathrm{u}_{\mathrm{i}, \mathrm{t}} \\
& \text { (1b) } \mathrm{Y}_{\mathrm{i}, \mathrm{t}}=\varphi_{\mathrm{i}}+\alpha_{1} \mathrm{~L}_{\mathrm{i}, \mathrm{t}}+\alpha_{2} \mathrm{~K}_{\mathrm{i}, \mathrm{t}}+\mathrm{v}_{\mathrm{i}, \mathrm{t}}-\mathrm{u}_{\mathrm{i}, \mathrm{t}} \\
& \text { where } \mathrm{v}_{\mathrm{i}, \mathrm{t}} \sim \mathrm{N}\left[0, \sigma_{\mathrm{v}_{\mathrm{i}, \mathrm{t}}}^{2}\right], \mathrm{u}_{\mathrm{i}}=\left|\mathrm{N}\left[\mu_{\mathrm{i}}, \sigma_{\mathrm{u}}^{2}\right]\right| \text { and } \mu_{\mathrm{i}}=\delta^{\prime} \mathrm{z}_{\mathrm{i}}
\end{aligned}
$$

Equations (1a) and (1b) are production functions with two inputs, labour $\mathrm{L}_{\mathrm{i}}$ and capital $\mathrm{K}_{\mathrm{i}}$ for firms $\mathrm{i}=1, \ldots, 28$ and periods $\mathrm{t}=1881, \ldots, 1913$. Both inputs capital $\mathrm{K}$ and labour $\mathrm{L}$, as well as tons of coal output $Y$, are in logs. In addition, we estimate a translog production function using the specification proposed by Corbo and Meller (1979) and Greene (1980). Yet, the econometric results presented in Table 2 - see below - shows that the additional parameters in the translog model are insignificant and we therefore turn to the simpler Cobb-Douglas production function.

Furthermore, we have company- and period-specific random components $\mathrm{v}_{\mathrm{i}, \mathrm{t}}$ as well as companyand period-specific inefficiency components $u_{i, t}$. The term $v_{i, t}$ captures time- and companyspecific idiosyncratic effects, which are normally distributed with a mean of zero. The term $u_{i, t}$ captures company-specific inefficiencies. These company-specific inefficiencies are censored at zero and can follow different distributions. In the general setting outlined in equations (1a) and (1b), the company-specific inefficiencies follow a truncated normal distribution, which is only defined on the positive orthant with a possibly non-zero modus $\mu_{\mathrm{i}}$. The modus $\mu_{\mathrm{i}}$ can be parameterised by employing the mean of company-specific and time-invariant characteristics $z_{i}$. For example, we use the log of the average bonus payments to board members of corporation i during the period 1881-1913 to explain the firm specific technical inefficiency $\mathrm{u}_{\mathrm{i}}$; see equation (2). 


$$
\begin{aligned}
& \text { (2) } \mu_{\mathrm{i}}=\delta_{\mathrm{i}} \log \left(\text { Bonus }_{\mathrm{i}}\right) \\
& \text { with Bonus } \mathrm{-}_{\mathrm{i}}=\frac{\sum_{\mathrm{t}=1881}^{1913} \text { Bonus }_{\mathrm{i}, \mathrm{t}}}{\mathrm{T}_{\mathrm{i}}}
\end{aligned}
$$

In equation (2), $\mu_{\mathrm{i}}$ is the measure of firm-specific inefficiency, explained by the log of the mean bonus payments to board members of firm i during the years $1881, \ldots, \mathrm{T}_{\mathrm{i}}$ with observations for firm $i$. In addition, we employ the log of the mean dummy variable indicating cartel membership as a measure of market power and an additional corporate governance variable, the log of the mean debt ratio, to explain average inefficiency. In the baseline specification, we simply assume that $\mu_{\mathrm{i}}=0$, i.e., we do not explain productive inefficiency. ${ }^{22}$

First of all, the regression yields the parameters of the production function. We can therefore identify the relative importance of capital and labour in the production process. Second, the sum of the regression coefficients $\alpha_{1}$ and $\alpha_{2}$ (or $\mathrm{a}_{1}$ and $\mathrm{a}_{2}$ ) can be used to test whether the production function has constant returns to scale. Finally, we can calculate productive inefficiency for each firm according to Jondrow et al. (1982). Moreover, the aggregate inefficiency for the whole population of firms can be calculated as the mean of company-specific inefficiencies.

\section{Results}

Table 2 shows the results using the translog production function (1a), whereas Table 3 shows the results using the more restrictive Cobb-Douglas production function (1b). Both production functions are estimated using three different specifications regarding the distributions of the firmspecific inefficiency term. The baseline specification is a fixed effects model with the additional assumption that the firm-specific inefficiencies follow a half-normal distribution with modus 0 . In addition, we check the distributional assumption for the inefficiency term by comparing it with models using a truncated normal or an exponential distribution for the inefficiency term.

The decisive difference between the translog production function and the Cobb-Douglas production function is that the former does not restrict the values of the elasticity of substitution and it does not assume strong separability among input factors. It turns out that all additional parameters of the function are nearly zero and insignificant in all three specifications. ${ }^{23}$ Furthermore, the variance parameters $\sigma$ and $\lambda$ are not identified if we employ the truncated normal assumption

22 We estimate the deep parameters of equations (1a), (1b), and (2) using maximum-likelihood (for details, see Horrance and Schmidt, 1996).

23 The insignificance of the additional coefficients is most likely induced by multicollinearity of $\mathrm{K}$ and $\mathrm{L}$ with $\mathrm{K}^{*} \mathrm{~L}, \mathrm{~K}^{2}$, and $\mathrm{L}^{2}$. Therefore, following Greene (1980), translog production functions are estimated using a system approach. Yet, the decomposition of the translog production function into single equations rests on the assumptions of competitive markets and constant returns to scale. Both assumptions are most likely not fulfilled in our setting and we therefore opt for the simple Cobb-Douglas production function. Moreover, this keeps our results comparable to Holtfrerich's (1973) results, which are based on a Cobb-Douglas production function. 
regarding the distribution of the inefficiency term. Consequently, we do not employ this variant of the stochastic frontier model in the following analysis. Finally, the results presented in Table 2 - as well as those presented in Table 3 - point to the superiority of the exponential model, using the log-likelihood as a measure. However, the exponential specification is only available for the simple estimation of technical inefficiency. It is not possible to employ the exponential model if the aim is to parameterize the inefficiency term. Yet, the point estimates of the production function are quite similar for all three specifications. Consequently, the imprecision resulting from employing the normal-half normal model should be small.

Table 2: Baseline regression results I: Translog-production function

Dependent variable: Log of coal output in tons

\begin{tabular}{|c|c|c|c|c|c|c|}
\hline & \multicolumn{2}{|c|}{$\begin{array}{c}\text { Regression I } \\
\text { Half-normal model }\end{array}$} & \multicolumn{2}{|c|}{$\begin{array}{c}\text { Regression II } \\
\text { Truncated normal model }\end{array}$} & \multicolumn{2}{|c|}{$\begin{array}{c}\text { Regression III } \\
\text { Exponential model }\end{array}$} \\
\hline & Coefficient & p-value & Coefficient & p-value & Coefficient & p-value \\
\hline Log(labour) & 0.650 & 0.000 & 0.593 & 0.000 & 0.592 & 0.000 \\
\hline Log(capital) & 0.146 & 0.187 & 0.152 & 0.221 & 0.152 & 0.151 \\
\hline $\log (\text { labour })^{2}$ & -0.012 & 0.486 & 0.002 & 0.899 & 0.002 & 0.897 \\
\hline $\log (\text { capital) })^{2}$ & -0.007 & 0.266 & -0.004 & 0.519 & -0.004 & 0.528 \\
\hline Log(labour)*Log(capital) & 0.023 & 0.298 & 0.011 & 0.566 & 0.011 & 0.616 \\
\hline Wald-test on constant returns to scale & 0.796 & 0.000 & 0.745 & 0.000 & 0.744 & 0.000 \\
\hline$\lambda$ or $\tau$ & 2.544 & 0.000 & 24.907 & 0.951 & 11.392 & 0.000 \\
\hline$\sigma$ & 0.169 & 0.000 & 1.754 & 0.951 & 0.071 & 0.000 \\
\hline Number of cross sections & \multicolumn{2}{|l|}{28} & \multicolumn{2}{|c|}{28} & \multicolumn{2}{|l|}{28} \\
\hline Number of observations & \multicolumn{2}{|c|}{633} & \multicolumn{2}{|c|}{633} & \multicolumn{2}{|c|}{633} \\
\hline Log likelihood & \multicolumn{2}{|c|}{503.6} & \multicolumn{2}{|c|}{518.7} & \multicolumn{2}{|c|}{518.8} \\
\hline
\end{tabular}

Method: Fixed-effects stochastic frontier. Log(labour) is log of employees. Log(capital) is

log of capital stock calculated from accounting data using perpetual inventory method.

The parameter values of the production function displayed in Tables 2 and 3 indicate that coal mining in the late $19^{\text {th }}$ - and early $20^{\text {th }}$ - century Ruhr district was labour intensive, with slightly decreasing economies of scale: the sum of the coefficients for labour (0.837) and capital (0.093) takes a value significantly below one (see Table 3, Regression I). In part, this result concurs with the literature on coal mining in the Ruhr district. The great importance of the production factor labour is a common theme in studies on mining in the Ruhr district. Empirical evidence is presented by Effertz (1895: 9) and Jüngst (1906: 14-18). They find that labour costs constituted roughly 60 percent of the total costs per ton of coal in the Ruhr district. Moreover, Holtfrerich's (1973: 89-90) estimates of the shares of capital and labour in net value added emphasise the great importance of the latter factor. 
Table 3: Baseline regression results II: Cobb-Douglas-production function

Dependent variable: Log of coal output in tons

\begin{tabular}{|c|c|c|c|c|c|c|}
\hline & \multicolumn{2}{|c|}{$\begin{array}{l}\text { Regression I } \\
\text { Half-normal model }\end{array}$} & \multicolumn{2}{|c|}{$\begin{array}{c}\text { Regression II } \\
\text { Truncated normal model }\end{array}$} & \multicolumn{2}{|c|}{$\begin{array}{c}\text { Regression III } \\
\text { Exponential model }\end{array}$} \\
\hline & Coefficient & p-value & Coefficient & p-value & Coefficient & p-value \\
\hline Log(labour) & 0.837 & 0.000 & 0.806 & 0.000 & 0.806 & 0.000 \\
\hline Log(capital) & 0.093 & 0.000 & 0.117 & 0.000 & 0.117 & 0.000 \\
\hline Wald-test on constant returns to scale & 0.930 & 0.000 & 0.923 & 0.000 & 0.923 & 0.000 \\
\hline$\lambda$ or $\tau$ & 2.509 & 0.000 & 24.077 & 0.953 & 11.519 & 0.000 \\
\hline$\sigma$ & 0.168 & 0.000 & 1.733 & 0.953 & 0.718 & 0.000 \\
\hline Number of cross sections & \multicolumn{2}{|l|}{28} & \multicolumn{2}{|c|}{28} & \multicolumn{2}{|c|}{28} \\
\hline Number of observations & \multicolumn{2}{|c|}{633} & \multicolumn{2}{|c|}{633} & \multicolumn{2}{|c|}{633} \\
\hline Log likelihood & \multicolumn{2}{|c|}{502.9} & \multicolumn{2}{|c|}{516.9} & \multicolumn{2}{|c|}{517.0} \\
\hline
\end{tabular}

Method: Fixed-effects stochastic frontier. Log(labour) is log of employees. Log(capital) is

log of capital stock calculated from accounting data using perpetual inventory method.

Other econometric results conflict with conventional views on coal mining in the Ruhr district. Our finding that there are decreasing returns to scale is at odds with the dominant view in both contemporary and modern studies. The former commonly note that fixed costs in coal mining were substantial and that, in general, increases in output were accompanied by decreasing average costs (Reuss, 1892: 77). However, marginal costs are not considered, because almost all of the contemporary writers have been influenced by the non-marginalistic German historical school of economics. Holtfrerich (1973), on the other hand, argues for constant returns to scale. He states that for contemporaries engaged in mining, the introduction of vertically sunk extraction shafts meant access to a practically indefinite number of equally profitability coal deposits. ${ }^{24}$ Moreover, he holds that increasing output by reaching out to deeper seated coal seams had mixed effects on returns to scale, which levelled each other out. On the one hand, the underground transportation distance for the extracted coal increased; but on the other hand, due to the geology of the Ruhr district, deeper seated coal seams were generally thicker and flatter and more evenly stratified than those closer to the surface.

Our estimates offer no support for the views of contemporaries. Moreover, Holtfrerich (1973) seems too optimistic about the positive effects of vertically sunk shafts. Without doubt, introducing them dramatically increased the number of accessible coal deposits. However, there still was a large amount of uncertainty about the stratification of coal seams, even those near existing production facilities. In addition, Holtfrerich omits increases in output that were achieved by expanding the horizontal dispersion of mining activity, where the prospect of more rewarding coal

24 Holtfrerich implicitly says that the Hotelling effect (Hotelling, 1931) was overcome. Hotelling states that productivity in mining will decline over time, if deposits are fixed and known, technological progress is constant, and deposits are extracted in order of their quality (starting with the best). Following Holtfrerich, with the adoption of vertical shafts the definity of deposits and thus also the necessarily declining quality of the extracted seams were no longer given for contemporaries engaged in coal mining. 
seams was less probable than in cases where an output expansion was achieved by reaching to deeper deposits. Furthermore, he seemingly underestimates the negative repercussions of rising production. First, a larger dispersion of mining activity in any direction was not only accompanied by increases in the underground transportation distance of the extracted coal. Of equal importance was the fact that it also lengthened the distance of the workers to the actual extraction points. ${ }^{25}$ It also meant that the surveillance of workers became increasingly difficult and costly. Second, the costs of preparing, maintaining, and securing coal seams, as well as those of dehydration and ventilation, increased over-proportionally to rising production. Moreover, until 1903, the cartel contract set an incentive to add new shafts to the production sites to get a higher quota. Therefore, the size and distribution of investments was influenced by the design of the cartel contract. Consequently, inefficient investments could induce inefficiencies. In a nutshell, there are various reasons for our finding of decreasing returns to scale. Innovations, e.g., changes in the extraction methods, the mechanisation of transportation and the extraction, were slowly starting to be adopted in the 1890s. However, up to the First World War, much of what would have been recommended was still at an experimental stage. Moreover, partial innovations at one stage of the production process had negative repercussions on other links in the chain (Burghardt, 1995).

Of greater interest for our main research question are the results for the inefficiency parameter. The parameters of the production function estimated by our baseline regression using the CobbDouglas production function and the assumption of a half-normally distributed error term lead to an estimation of the mean inefficiency of Ruhr coal mining corporations of about 11.7 percent. ${ }^{26}$

To deepen the analysis, we test whether certain variables - e.g., proxies for product market competition or the quality of corporate governance - influenced productive efficiency. Table 4 displays the results of equations (1b) and (2) if we allow for a heterogeneous mean $\mu_{\mathrm{i}}$. The results regarding the coefficients of the production function are not much influenced by the inclusion of a heterogeneous mean for the inefficiency term.

25 From 1889 onwards - as a result of a mine worker strike - the time getting to the extraction points was increasingly considered part of the working hours (Jüngst, 1908: 134).

26 The mean inefficiency derived from the truncated normal (exponential) model is 8.4 (8.5) percent. 
Table 4: Explaining productive efficiency

Dependent variable: Log of coal output in tons

\begin{tabular}{|c|c|c|c|c|c|c|}
\hline & \multicolumn{2}{|c|}{ Regression I } & \multicolumn{2}{|c|}{ Regression II } & \multicolumn{2}{|c|}{ Regression III } \\
\hline & Coefficient & $p$-value & Coefficient & p-value & Coefficient & p-value \\
\hline Log(labour) & 0.831 & 0.000 & 0.835 & 0.000 & 0.822 & 0.000 \\
\hline Log(capital) & 0.099 & 0.000 & 0.095 & 0.000 & 0.106 & 0.000 \\
\hline $\begin{array}{l}\text { Wald-test on constant returns } \\
\text { to scale }\end{array}$ & 0.930 & 0.000 & 0.930 & 0.000 & 0.928 & 0.000 \\
\hline $\begin{array}{l}\text { Log of mean of firm specific } \\
\text { RWKS membership } \\
\text { Log of mean of firm specific } \\
\text { debt ratio }\end{array}$ & 0.011 & 0.844 & 0.009 & 0.846 & 0.101 & 0.516 \\
\hline $\begin{array}{l}\text { Log of mean of firm specific } \\
\text { bonus payments (in 1,000 Mark) }\end{array}$ & -0.035 & 0.059 & & & -0.043 & 0.090 \\
\hline$\lambda$ & 3.347 & 0.000 & 2.509 & 0.000 & 3.676 & 0.000 \\
\hline$\sigma$ & 0.233 & 0.000 & 0.169 & 0.000 & 0.262 & 0.000 \\
\hline Number of cross sections & 28 & & 28 & & 28 & \\
\hline Number of observations & 633 & & 633 & & 633 & \\
\hline Log likelihood & 510. & & 502. & & 511.2 & \\
\hline
\end{tabular}

It turns out that company-specific inefficiency cannot be explained using the RWKS membership dummy (see Table 4, Regression II). The coefficient is statistically insignificant. However, a dummy variable might be too imprecise to measure the effects of the cartel. Consequently, we use additional information available for a sub-sample of our firms to calculate the price-cost margin of coal mines. The results presented in Table 5, Regression I, show, however, that the price-cost margin is - like the RWKS dummy variable - statistically insignificant.

Furthermore, standard oligopoly theory shows that a merger of firms in a Cournot oligopoly will not increase the joint-profit of the merged firms, but instead increase the profits of the remaining independent market participants (Shapiro and Farrell, 1990). A similar argument could be at work in the case of the RWKS: the cartel reduced the product market competition not only for the cartel members, but also for the non-cartelized firms. Thus, the productive efficiency of all firms should decline after the cartel formation in 1893. Yet, the results shown in Table 5, Regression II show that a post-1893 dummy variable, which should pick up this effect, is statistically insignificant. 
Table 5: Explaining productive efficiency - Stability tests

Dependent variable: Log of coal output in tons

\begin{tabular}{|c|c|c|c|c|}
\hline & \multicolumn{2}{|c|}{ Regression I } & \multicolumn{2}{|c|}{ Regression II } \\
\hline & Coefficient & p-value & Coefficient & $p$-value \\
\hline Log(labour) & 0.818 & 0.000 & 0.846 & 0.000 \\
\hline Log(capital) & 0.078 & 0.137 & 0.089 & 0.000 \\
\hline $\begin{array}{l}\text { Wald-test on constant returns } \\
\text { to scale }\end{array}$ & 0.896 & 0.000 & 0.935 & 0.000 \\
\hline Post-1893 dummy & & & 0.029 & 0.279 \\
\hline Log of mean of price-cost margin & 0.025 & 0.755 & & \\
\hline$\lambda$ & 1.887 & 0.000 & 2.442 & 0.000 \\
\hline$\sigma$ & 0.145 & 0.000 & 0.163 & 0.000 \\
\hline Number of cross sections & \multicolumn{2}{|c|}{13} & \multicolumn{2}{|c|}{28} \\
\hline Number of observations & \multicolumn{2}{|c|}{232} & \multicolumn{2}{|c|}{633} \\
\hline Log likelihood & \multicolumn{2}{|c|}{214.5} & \multicolumn{2}{|c|}{503.2} \\
\hline
\end{tabular}

Therefore, we take an intermediate position between the views regarding the impact of cartels on productive efficiency. On the one hand, Feldenkirchen (1982: 113) and Wengenroth (1998) based their hypotheses on these contemporaries' views that cartels hampered the cost efficiency of cartelised companies. On the other hand, Pierenkemper (2000: 236, 244) figured out that the only way to increase firm profits was to reduce costs, since output prices were fixed by the cartel. Therefore, cartels should have improved cost efficiency. Our results show that cartel formation did not affect the productive efficiency of coal mines.

Furthermore, in the specification underlying the results of Table 4, we aim to explain productive efficiency by differences in the corporate governance of firms. In particular, we investigate whether performance-related managerial compensation or differences in the financial structure of the corporations can explain productive inefficiency. The relationship between product market competition, financial structure, and managerial incentives is debated by modern economists. On the one hand, lower product market competition may weaken the incentives of agents since principals are worse informed about agents' actions (Hart, 1983) or because the threat of bankruptcy declines with rising market power (Schmidt, 1997). Yet, the risk of bankruptcy can be increased by altering the financial structure of firms. Firms with a higher debt ratio can reduce the monetary motivation of managers (Aghion et al., 1999). Moreover, debt holders, e.g., bankers, also monitor agents' efforts, and if creditors detect managerial inefficiency, creditors might call in their money, thereby increasing the liquidation risk of the firm. ${ }^{27}$ On the other hand, declining product-market competition increases the marginal return of managerial effort, and therefore weaker product market competition can induce the manager to work harder (Schmidt, 1997). Moreover, since market shares, output, and prices were more or less fixed by the cartel agreement, the only possible way to increase profits was to lower costs, i.e., to be more efficient. Fi-

27 Fohlin (2007, Chapter 5) provides an excellent review of the relevance of bank monitoring during the late 19 th and early 20 th century for firm performance. 
nally, weak product-market competition can alter the market structure since new firms enter the market. A model by Raith (2003) predicts that new companies will intensify competition and the marginal return of managerial effort will thus remain constant. Moreover, he shows that lower competition accompanies lower managerial incentives. However, Raith's (2003) model critically depends on the possibility of market entry. Yet, several barriers kept new firms from the market. First of all, opening a new mine was very costly. The initial sunk costs were several million Marks. In addition, exploration techniques were less developed than today; therefore opening a new mine was very risky. Finally, the 1903 cartel treaty explicitly mentioned strategies to bar new firms. The cartelised firms bought unexploited coal fields, and the RWKS was authorized to start a price war if non-cartelised firms entered the market.

It turns out that productive inefficiency is influenced significantly by bonus payments to board members, whereas the financial structure of corporations is insignificant in explaining efficiency. ${ }^{28}$ Nevertheless, performance-related managerial compensation was much more strongly used in cartelized firms. The level of shares in profits paid before and after cartel formation differed significantly. Before cartel formation, the average board received 3.7 percent of company profits. After cartel formation in 1893, the board of a non-cartelised company received a share in profits of 2.5 percent, whereas the board of a cartelised firm received a share in profits of 3.6 percent on average.

At first glance, the coefficient measuring the efficiency gains of managerial compensation seems to be quite small. An increase of bonus payments to the board by one per cent reduces technical inefficiency by about 0.0035 percent. Yet, the monetary equivalent of technical inefficiency is much larger than the value of bonus payments. On average, about 73,000 Mark were paid out as a bonus to the board. Thus, an increase of one per cent equals about 730 Mark. This compares to 'average costs' of a firm of about 193.7 million Mark. ${ }^{29}$ Mean inefficiency of a firm is about 11.7 per cent, or 22.66 million Mark. Therefore, a 0.0035 per cent reduction of technical inefficiency equals about 790 Mark. Thus, the cost reductions are slightly higher than the additional bonuses paid. Thus, it seems that managers adjusted their efforts to generate higher profits via reduced costs according to the incentives set in their working contracts.

\section{Conclusion}

One pillar of the accepted view of the economic history of the German Empire is that it was a nation of cartels. There is some truth in this view, since several hundred cartels existed in preWorld War I Germany. Moreover, at least from 1897 onwards, cartel agreements were judicially

28 This finding has some relevance for industrial economics in general, since the empirical literature on the relationship between management compensation and productive efficiency is sparse; see Habib and Ljungqvist (2005) and Beak and Pagan (2002) for recent contributions.

29 ,Average costs' are calculated as the market price of coal times the output of a firm less the accounting profits. 
enforceable, facilitating the foundation and durability of cartels. However, the economic consequences of cartels and their impact on German industrialisation have not been fully identified.

Standard theory suggests that cartels should lead to excess profits for cartelized firms. The redistribution of the consumer surplus to producers and the aggregate decline in output should induce social losses. In addition, in a world with asymmetric information between owners of a cartelized mining corporation and managers, the latter group must be motivated by incentives. Otherwise, managers could use market power to enjoy a quiet life, instead of the hard life of profitmaximising agents. If so, reduced product market competition in a cartelised country can induce companies to become less cost efficient.

Recent research has produced conflicting views regarding the effects of cartels in general and the RWKS in particular on firm performance in the German Empire. First, Wengenroth (1998) and Feldenkirchen (1982: 113) hypothesised that cartelised firms lost flexibility in enacting a dynamic corporate strategy and therefore the cartel hampered the growth of total factor productivity and the static cost efficiency of the cartelised corporations. Second, Bittner $(2002,2005)$ showed that the formation of the RWKS is invisible in the stock market returns of the firms forming the cartel. This supports a hypothesis of Born (1985: 44). According to him, the RWKS was unimportant for the development of coal mining in the Ruhr area since it was neither successful in increasing output prices nor in reducing the rate of output growth. Third, Pierenkemper (2000: $236,244)$ hypothesised that the cartel was successful since it stabilised coal prices and led to higher revenues for the cartelized companies. Moreover, since the price was fixed by the RWKS, the only mechanism available to managers to increase firm profits was cost reduction. Therefore, cartel formation induced higher cost efficiency.

The findings of our paper mostly agree with the intermediate position taken by Bittner (2002, 2005) and Born (1985): The formation of the RWKS did not have a measurable effect on the technical efficiency of the cartelised firms. Yet, we can also partly support Pierenkemper's (2000) claim that cost reduction was a successful strategy, at least if managers of the firms participated from the increased firm profits. Jointly and severally, even the supposedly most important cartel in Imperial Germany did not have a measurable impact on the technical efficiency of cartelised firms. Therefore the relevance of cartelisation on the German industrialisation might be less pronounced than classical accounts suggest. 


\section{References}

\section{Primary Sources}

Der Deutsche Ökonomist, 1883-1889

Jahrbuch für den Oberbergamtsbezirk Dortmund, 2-14, 1894-1922

Saling’s Börsen-Jahrbuch. Ein Handbuch für Bankiers und Kapitalisten. Zweiter (finanzieller) Teil, 5-38, 1881-1914

State Archive Münster, Bestand Oberbergamt Dortmund, No. 88-101

Zeitschrift für das Berg-, Hütten- und Salinen-Wesen im preussischen Staate, 30-41, 1882-1893

\section{Secondary Sources}

Aghion, Philippe / Dewatripont, Mathias / Rey, Patrick (1999)

Competition, financial discipline, and growth

Review of Economic Studies, 66, 1999, 825-852

Aigner, D. / Lovell, K. / Schmidt, P. (1977)

Formulation and estimation of stochastic frontier production function models

Journal of Econometrics, 6, 1977, 21-37

Audretsch, David B. (1989)

Legalized cartels in West Germany

Antitrust Bulletin, 34, 1989, 579-600

Baek, H. Young / Pagan, José A. (2002)

Executive compensation and corporate production efficiency: A stochastic frontier approach

Quarterly Journal of Business \& Economics, 41, 2002, 27-41

Battese, G. / Coelli, T. (1988)

Prediction of firm-level technical efficiencies with a generalized frontier production function and panel data

Journal of Econometrics, 38, 1988, 387-399

Battese, G. / Coelli, T. (1995)

A model for technical inefficiency effects in a stochastic frontier production function for panel data

Empirical Economics, 20, 1995, 325-332 
Bergmann, Kurt (1937)

Die wirtschaftliche Entwicklung des Ruhrkohlenbergbaus seit Anfang des 19 Jahrhunderts Köln: F. Flothmann

Bittner, Thomas (2002)

Kartelle und Wachstum im deutschen Kaiserreich: Wirtschaftshistorische Erkenntnisse und industrieökonomische Forschungsperspektiven

Jahrbuch für Wirtschaftsgeschichte, 2002/2, 209-229

Bittner, Thomas (2005)

An event study of the Rhine-Westphalian Coal Syndicate

European Review of Economic History, 9, 2005, 337-364

Born, Karl Erich (1985)

Wirtschafts- und Sozialgschichte des Deutschen Kaiserreichs (1867/ 71 - 1914)

Franz Steiner Verlag, Wiesbaden 1985

Bosenick, Alfred (1906)

Der Steinkohlenbergbau in Preussen und das Gesetz des abnehmenden Ertrages

Zeitschrift für die Gesamte Staatswissenschaft, Supplement 19, 1-114

Broadberry, Stephen N. / Crafts, Nicholas F.R. (1992)

Britain's productivity gap in the 1930s: Some neglected factors

Journal of Economic History, 52, 1992, 531-558

Brown, Peter Charles (1993)

From competition to cartel. A study of the Ruhr coal industry during the $19^{\text {th }}$ century

University of Wolverhampton: unpublished dissertation

Burghardt, Uwe (1995)

Die Mechanisierung des Ruhrbergbaus, 1890-1930

München: C. H. Beck

Burhop, Carsten / Wolff, Guntram B. (2005)

A compromise estimate of German net national product, 1851-1913, and its implications for growth and business cycles

Journal of Economic History, 65, 2005, 613-657

Chandler, Alfred Dupont (1990)

Scale and scope

Belknap Press, Cambridge / Mass. 1990 
Cheffins, Brian R. (2003)

Mergers and corporate ownership structure: The United States and Germany at the turn of the twentieth century

American Journal of Comparative Law, 51, 2003, 473-503

Corbo, Vittorio / Meller, Patricio (1979)

The translog production function: Some evidence from establishment data Journal of Econometrics, 10, 1979, 193-199

Effertz, R. (1895)

Die niederrheinisch-westfälische Kohlen-Industrie in ihren Existenzbedingungen früher und jetzt

Essen: Baedeker

Feldenkirchen, Wilfried (1982)

Die Eisen- und Stahlindustrie des Ruhrgebiets 1879-1914

Franz Steiner Verlag, Wiesbaden 1982

Fine, Ben (1990)

Economies of scale and a featherbedding cartel? A reconsideration of British interwar coal industry

Economic History Review, 43, 1990, 438-449

Fohlin, Caroline (2007)

Finance capitalism and Germany's rise to industrial power

Cambridge University Press, Cambridge 2007

Friedrich, Wolfgang (1979)

Die Entwicklung des Rechts der bergrechtlichen Gewerkschaft in Preußen von 1850 bis zum Ersten Weltkrieg

In: Horn, Norbert / Kocka, Jürgen (eds.): Recht und Entwicklung der Großunternehmen im 19. und frühen 20. Jahrhundert. Wirtschaft-, Sozial- und Rechtshistorische Untersuchungen zur Industrialisierung in Deutschland, Frankreich, England und den USA, Göttingen: Vandenhoeck und Ruprecht, 190-203

Gerschenkron, Alexander (1962)

Economic backwardness in historical perspective

Belknap Press, Cambridge / Mass. 1962

Goldschmidt, Curt (1912)

Über die Konzentration im deutschen Kohlenbergbau. Eine ökonomische Studie

Karlsruhe: C. Braunsche Hofbuchdruckerei 
Greene, William H. (1980)

On the estimation of a flexible frontier production function

Journal of Economtrics, 13, 1980, 101-115

Greene, William H. (2003)

Econometric Analysis

$5^{\text {th }}$ Edition, Pearson Education International, Upper Saddle River 2003

Greene, William H. (2005)

Fixed and random effects in stochastic frontier models

Journal of Productivity Analysis, 23, 2005, 7-32

Habib, M.A. / Ljungqvist, A. (2005)

Firm value and managerial incentives: A stochastic frontier approach

Journal of Business, 78, 2005, 2053-2093

Hart, Oliver D. (1983)

The market mechanism as an incentive scheme

Bell Journal of Economics, 14, 1983, 366-382

Hicks, John R. (1935)

Annual survey of economic theory: The theory of monopoly

Econometrica, 3, 1935, 1-20

Hoffmann, W.G. (1965)

Das Wachstum der deutschen Wirtschaft seit der Mitte des 19. Jahrhunderts Springer Verlag, Berlin

Holtfrerich, Carl-Ludwig (1973)

Quantitative Wirtschaftsgeschichte des Ruhrkohlenbergbaus im 19. Jahrhundert

Dortmund: Gesellschaft für Westfälische Wirtschaftsgeschichte

Horrace, William C. / Schmidt, Peter (1996)

Confidence statements for efficiency estimates from stochastic frontier models

Journal of Productivity Analysis, 7, 1996, 257-282

Hotelling, Harold (1931)

The Economics of Exhaustible Resources

Journal of Political Economy 39, 137-175 
Huske, Joachim (1987)

Die Steinkohlenzechen im Ruhrrevier: Daten und Fakten von den Anfängen bis 1986

Bochum: Deutsches Bergbau-Museum

Jondrow, James / Lovell, C.A. Knox / Materov, Ivan S. / Schmidt, Peter (1982)

On the estimation of technical inefficiency in the stochastic frontier production function model

Journal of Econometrics, 19, 1982, 233-238

Jüngst, Ernst (1906)

Arbeitslohn und Unternehmensgewinn im Rheinisch-Westfälischen Steinkohlenbergbau

Essen: Verein für die bergbaulichen Interessen im Oberbergamtsbezirk Dortmund

Jüngst, Ernst (1908)

Festschrift zur Feier des fünfzigjährigen Bestehens des Vereins für die bergbaulichen Interessen im Oberbergamtsbezirk Dortmund in Essen, 1858-1908

Essen: Glückauf

Kocka, Jürgen (1978)

Entrepreneurs and managers in German industrialisation

In: Mathias, Peter / Postan, M.M. (eds.): The Cambridge Economic History of Europe, Volume VII, Cambridge University Press, Cambridge 1978, 492-589

Landes, David (1969)

The unbound Prometheus

Cambridge University Press, Cambridge 1969

Levenstein, Margaret C. / Suslow, Valerie Y. (2006)

What determines cartel success?

Journal of Economic Literature, 44, 43-95

Lindenberg, Eric B. / Ross, Stephen A. (1981)

Tobin's q Ratio and Industrial Organization

Journal of Business, 54, 1981, 1-32

Martin, Stephen (1994)

Industrial Economics. Economic Analysis and Public Policy

$2^{\text {nd }}$ Edition, Macmillan, New York 1994

Parnell, Martin (1994)

The German tradition of organized capitalism

Clarendon Press, Oxford 1994 
Passow, R. (1911)

Materialien für das wirtschaftswissenschaftliche Studium. Die Kartelle des Bergbaus

Leipzig: Teubner

Peters, Lon LeRoy (1981)

Cooperative competition in German coal and steel, 1893-1914

Yale University: unpublished dissertation

Peters, Lon LeRoy (1989)

Managing competition in German coal, 1893-1913

Journal of Economic History, 49, 1989, 419-434

Pierenkemper, Toni (1992)

Die schwerindustriellen Regionen Deutschlands in der Expansion: Oberschlesien, die Saar und das Ruhrgebiet im 19. Jahrhundert

Jahrbuch für Wirtschaftsgeschichte, 1992/1, 37-56

Pierenkemper, Toni (2000)

Unternehmensgeschichte

Franz Steiner Verlag, Stuttgart 2000

Raith, Michael (2003)

Competition, risk, and managerial incentives

American Economic Review, 93, 2003, 1425-1436

Reuss, Max (1892)

Mittheilungen aus der Geschichte des Königlichen Oberbergamtes zu Dortmund und des niederrheinisch-westfälischen Bergbaues

Berlin: Ernst

Schmidt, Klaus M. (1997)

Managerial incentives and product market competition

Review of Economic Studies, 64, 1997, 191-213

Shapiro, C. / Farrell, J. (1990)

Horizontal mergers - an equilibrium analysis

American Economic Review, 80, 1990, 107-126

Sickles, Robin C. (2005)

Panel estimators and the identification of firm-specific efficiency levels in parametric, semiparametric and nonparametric setting

Journal of Econometrics, 126, 2005, 305-334 
Stevenson, Rodney E. (1980)

Likelihood functions for generalized stochastic frontier estimation

Journal of Econometrics, 13, 1980, 57-66

Tullock, Gordon (1967)

The welfare costs of tariffs, monopolies, and theft

Western Economic Journal, 5, 1967, 224-232

Verein für die bergbaulichen Interessen im Oberbergamtsbezirk Dortmund (1904a)

Die Entwickelung des Niederrheinisch-Westfälischen Steinkohlenbergbaues in der zweiten Hälfte des 19. Jahrhunderts, Vol. 10: Wirtschaftliche Entwickelung, Teil 1

Berlin: Julius Springer

Verein für die bergbaulichen Interessen im Oberbergamtsbezirk Dortmund (1904b)

Die Entwickelung des Niederrheinisch-Westfälischen Steinkohlenbergbaues in der zweiten Hälfte des 19. Jahrhunderts, Vol. 11: Wirtschaftliche Entwickelung, Teil 2

Berlin: Julius Springer

Wald, A. / Wolfowitz, J. (1940)

On a test whether two samples are from the same population

Annals of Mathematical Statistics, 11, 1940, 147-162

Walker, Francis (1904)

Monopolistic combinations in the German coal industry

New York: Macmillan

Webb, Steven B. (1980)

Tariffs, cartels, technology, and growth in the German steel industry, 1897-1914

Journal of Economic History, 40, 309-329

Wengenroth, Ulrich (1998)

Krisen in der deutschen Stahlindustrie

In: Friedrich-Wilhelm Henning (Ed.): Krisen und Krisenbewältigung, Fritz Lang Verlag, Frankfurt am Main 1998, 70-91

Wiedenfeld, Kurt (1912)

Das Rheinisch-Westfälische Kohlensyndikat

Bonn: A. Marcus und E. Webers

Winston, Clifford (1998)

U.S. industry adjustment to economic deregulation

Journal of Economic Perspectives, 12, 1998, 89-110 
Zitzewitz, Eric W. (2003)

Competition and long-run productivity growth in the UK and US tobacco industries, 18791939. Journal of Industrial Economics, 51, 2003, 1-33 
Appendix 1: Data sources

\begin{tabular}{|l|l|}
\hline Average Costs in Marks & $\begin{array}{l}\text { Der Deutsche Ökonomist, 1883-1889 } \\
\text { Jahrbuch für den Oberbergamtsbezirk Dortmund, 2-14, } \\
1894-1922\end{array}$ \\
\hline Average Revenues in Marks & $\begin{array}{l}\text { Der Deutsche Ökonomist, 1883-1889 } \\
\text { Jahrbuch für den Oberbergamtsbezirk Dortmund, 2-14, } \\
1894-1922\end{array}$ \\
\hline Coal Output in tons & $\begin{array}{l}\text { Huske (1987) } \\
\text { Jahrbuch für den Oberbergamtsbezirk Dortmund, 2-14, } \\
1894-1922\end{array}$ \\
& $\begin{array}{c}\text { State Archive Münster, Bestand Oberbergamt Dortmund, } \\
\text { No. 88-101 } \\
\text { Zeitschrift für das Berg-, Hütten- und Salinen-Wesen im } \\
\text { preussischen Staate, 30-41, 1882-1893 }\end{array}$ \\
\hline Labour Input & $\begin{array}{l}\text { Huske (1987) } \\
\text { Jahrbuch für den Oberbergamtsbezirk Dortmund, 2-14, } \\
1894-1922\end{array}$ \\
& State Archive Münster, Bestand Oberbergamt, No. 88- \\
& 101 \\
\hline Capital Input in Marks & Saling's Börsen-Jahrbuch. Zweiter (finanzieller) Teil, 5- \\
& 38, 1881-1914 \\
\hline
\end{tabular}




\section{Appendix 2: Sample of mining corporations}

\begin{tabular}{rlll}
\hline No. & Firm & RWKS $^{1}$ & Years \\
\hline 1 & Aplerbecker Aktien-Verein für Bergbau & 1893 & $1882-1913$ \\
2 & Arenbergsche AG für Bergbau und Hüttenbetrieb & 1893 & $1881-1913$ \\
3 & Bochumer Bergwerks-AG & 1893 & $1881-1913$ \\
4 & Bochumer Verein für Bergbau und Gusstahlfabrikation & 1903 & $1881-1913$ \\
5 & Bonifacius & 1893 & $1881-1898$ \\
6 & Concordia & 1893 & $1891-1913$ \\
7 & Consolidation & 1893 & $1890-1913$ \\
8 & Courl & 1893 & $1891-1898$ \\
9 & Dannebaum & 1893 & $1890-1899$ \\
10 & Dortmunder Bergbau-AG & 1893 & $1881-1894$ \\
11 & Essener Steinkohlenbergwerke & 1907 & $1907-1913$ \\
12 & Gelsenkirchener Bergwerks-AG & 1893 & $1881-1913$ \\
13 & Harperner Bergbau-AG & 1893 & $1881-1913$ \\
14 & Hibernia & 1893 & $1881-1913$ \\
15 & Hörder Bergwerks- und Hüttenverein & 1903 & $1881-1906$ \\
16 & Hoesch & 1903 & $1902-1913$ \\
17 & Hugo & 1893 & $1890-1894$ \\
18 & Kölner Bergwerks-Verein & 1893 & $1881-1911$ \\
19 & König Wilhelm & 1893 & $1881-1913$ \\
20 & Louise Tiefbau & 1893 & $1881-1907$ \\
21 & Magdeburger Bergwerks-AG & 1893 & $1881-1913$ \\
22 & Massen & 1893 & $1891-1910$ \\
23 & Nordstern & 1893 & $1890-1906$ \\
24 & Phönix & 1903 & $1897-1913$ \\
25 & Pluto & 1893 & $1881-1898$ \\
26 & Rheinische Anthracit-Kohlenwerke & 1893 & $1890-1905$ \\
27 & Rheinische Stahlwerke & 1903 & $1901-1913$ \\
28 & Union & 1903 & $1881-1910$ \\
\hline \hline
\end{tabular}

${ }^{1}$ Beginning of membership in the RWKS. 


\section{Appendix 3: Calculation of capital stock at replacement costs}

Following Lindenberg and Ross (1981), the replacement cost $(R C)$ of a firm at time $t$ is the sum of three summands:

- the total assets of the firm at this time $\left(T A_{t}\right)$,

- the difference between the firm's net plant at replacement cost in period $t$ and the historic value of its net plant in the same period $\left(R N P_{t}-H N P_{t}\right)$, and

- the difference between the firm's inventories at replacement cost in period $t$ and the historic value of its inventories in the same period $\left(R I N V_{t}-H I N V_{t}\right)$.

The inventories summand drops out, because contemporaries used to price their inventories at recent prices (Rettig, 1978) so that a firm's inventories at replacement cost are equal to the historic value of its inventories $\left(R I N V_{t}=H I N V_{t}\right.$, ). The amount of total assets and the net plant at historical value are taken directly from the balance sheets. The net plant at replacement costs is calculated by a recursive estimation procedure that accounts for investment, depreciation, price changes, and technical progress:

$$
R N P_{t}=\sum_{\tau=0}^{t} \prod_{s=t-1}^{t}\left[\frac{1+\phi_{s}}{\left(1+\delta_{s}\right)\left(1+\theta_{s}\right)}\right] * I_{\tau}+H N P_{0} * \prod_{s=0}^{t}\left[\frac{1+\phi_{s}}{\left(1+\delta_{s}\right)\left(1+\theta_{s}\right)}\right]
$$

$\varphi$ : Change of capital goods price index

$\delta$ : Depreciation rate

$\theta$ : Rate of technical progress

I: Investment

The capital goods price index is approximated by Hoffmann's (1965) machine price index; the rate of technical progress by the residual of a growth accounting exercise of the industrial sector (Burhop and Wolff, 2005). The depreciation rate was calculated by dividing the depreciation in period $t$ by the historical net plant in the preceding period; investment by subtracting the historical net plant in period $t-1$ from the historical net plant of the subsequent period and adding the depreciation of period $t$. 